\title{
UVODNA RIJEČ UREDNIKA TEMATSKOG BROJA
}

Na Pravnom fakultetu u Osijeku 26. listopada 2018. održana je Međunarodna znanstvena konferencija pod nazivom "Dosezi, stanje i perspektive - nasljedno pravo u Europskoj uniji". Konferenciju je organizirala Katedra građanskopravnih znanosti Pravnog fakulteta u Osijeku. Osim članova Katedre (prof. dr. sc. Vlado Belaj, doc. dr. sc. Davorin Pichler i doc. dr. sc. Dubravka Klasiček), u radu Organizacijskog odbora sudjelovali su i doc. dr. sc. Višnja Lachner s Pravnog fakulteta u Osijeku, izv. prof. Zsuzsanna Peres, National University of Public Service te doc. dr. sc. Mónika Csöndes, Corvinus University, obje iz Budimpešte, Mađarska; dr. sc. Edina Harbinja s Aston University, Birmingham iz Velike Britanije te izv. prof. Angel Ristov s Pravnog fakulteta "Justinijan Prvi” iz Skopja, Makedonija.

Konferencija je organizirana u povodu 15. godišnjice Zakona o nasljeđivanju Republike Hrvatske koji je stupio na snagu 2003. godine. Sastojala se od triju sesija - dviju službenih i jedne neslužbene, nazvane Student session, na kojoj su svoje radove iz područja nasljednog prava izlagali neki od najboljih studenata Pravnog fakulteta iz Osijeka.

Svoja istraživanja na temu nasljednog prava na službenom dijelu konferencije predstavilo je devetnaestero znanstvenika, koji su došli iz Bosne i Hercegovine, Srbije, Mađarske, Makedonije i Hrvatske. Radovi su obuhvatili teme kako iz područja povijesti nasljednog prava, tako i onih koji se tiču njegovih postojećih i budućih instituta. Većina je autora u svojim izlaganjima i poslije tijekom rasprave, izrazila stavove kako bi određene institute nasljednog prava u skorije vrijeme trebalo mijenjati. Autori su također donijeli osvrte na nasljednopravna uređenja država iz kojih su došli te je naglasak bio stavljen na uvođenje pojedinih instituta koji još ne postoje u nasljednim pravima pojedinih država. Tijekom rasprave, na vidjelo je izašlo kako postoje brojne sličnosti, no i znatne razlike u nasljednim pravima navedenih država.

U ovom broju Pravnog vjesnika objavljen je samo dio radova koji su izloženi na konferenciji.

Doc. dr. sc. Davorin Pichler u radu naslovljenom "Nasljednopravna raspolaganja u korist životinje" istražio je mogućnosti pravnih raspolaganja u korist životinje za slučaj smrti. S obzirom na to da se u suvremenim pravnim porecima ovakve situacije već događaju, samo je pitanje vremena kada će doći do potrebe njihove pravne regulacije i u hrvatskom nasljednom pravu. Autor je analizirao institute nasljednog prava de lege lata koji mogu predstavljati mehanizam raspolaganja imovinom u korist životinje za slučaj ostaviteljeve smrti. Također, naglasio je kako postoji potreba zakonske intervencije u Zakon o nasljeđivanju i Zakon o zakladama. Takva bi intervencija omogućila stvaranje oporučne zaklade u korist ljudskog korisnika, dok bi upravitelj zaklade vršio dodjelu sredstava korisniku za pokriće troškova koje korisnik zaklade ima za skrb nad životinjom.

Doc. dr. sc. Jelena Kasap i doc. dr. sc. Višnja Lachner u radu pod naslovom "Korčulanski statut i njegova nasljednopravna regulacija" obradile su nasljednopravnu regulaciju Korčulanskog statuta koja se temelji na elementima starog hrvatskog i slavenskog prava te se razlikuje od regulacije prisutne u statutima ostalih dalmatinskih gradova koje su nerijetko bili posljedica utjecaja bizantskog i kasnijeg hrvatsko-mađarskog prava Tripartita. Autorice naglašavaju kako je temeljna osobina ovakvog uređenja mogućnost da i muški i ženski potomci naslijede ostavinu umrloga. Iako su prema Koručalnskom statutu, muški potomci imali prednost 
pred ženskim potomcima istog stupnja srodstva, žene su ipak bile potencijalni nasljednici, dok prema hrvatsko-mađarskom pravu one uopće nisu imale mogućnost nasljeđivanja očevih nekretnina. U rada je ukazano na razlike glede pravnih temelja nasljeđivanja prisutnih u Korčulanskom i u drugim važnim statutima dalmatinskih gradova, pri čemu je posebna pozornost posvećena nasljednopravnom položaju udane žene kad je posrijedi mogućnost raspolaganja vlastitim dobrima, tj. mirazom.

Doc. dr. sc. Katarina Knol u radu “Odstupanje od načela jedinstva nasljeđivanja u Uredbi EU-a o nasljeđivanju” obradila je načelo jedinstva nasljeđivanja koje, u većini slučajeva, slijedi Uredba (EU) br. 650/2012 te je naglasak stavila na odstupanja koja, prije svega, postoje kada su u postupak nasljeđivanja uključene treće države. Kako autorica naglašava, cilj rada bio je analizirati u kojim slučajevima, na temelju Uredbe o nasljeđivanju, dolazi do fragmentacije nasljeđivanja i jesu li takva odstupanja opravdana. Autorica je također predložila uvođenje izmjena koje bi omogućile strankama da se sporazume da su sudovi trećih država odabranog prava i nadležni za rješavanje pitanja nasljeđivanja, pod uvjetom da su ti sudovi tada nadležni za odlučivanje o nasljeđivanju u cjelini. Također, jedan od prijedloga ide u smjeru uvođenja u Uredbu o nasljeđivanju posebnih pravila o priznavanju i izvršenju odluka o nasljeđivanju donesenih od sudova trećih država, što bi osiguralo veću razinu ujednačenosti u tretiranju trećih država u odnosu na države članice Europske unije i time osiguralo i veći stupanj uvažavanja jedinstvenog pristupa nasljeđivanju kao jednog od njegovih temeljnih načela.

Doc. dr. sc. Dubravka Klasiček u radu pod naslovom “ $21^{\text {st }}$ century wills” naglasila je kako su oporuke oduvijek strogo formalni pravni poslovi koji će, ako ne udovoljavaju strogim pretpostavkama, biti nevaljani. Naime, kako autorica navodi, pravila koja se odnose na oblik oporuke uvijek su bila stroga i zahtijevala da one budu sastavljene na točno određeni način, no danas se čini kako se taj formalizam katkad sukobljava s namjerom ostavitelja. Neke su države već usvojile pravila koja sucima omogućuju da dopuste određenim dokumentima, koji ne zadovoljavaju sve propisane formalnosti potrebne za oporuku, da imaju učinak oporuke. Time su se otvorila vrata stvaranju određenih novih vrsta oporuka koje su napravljene uz pomoć digitalnih tehnologija, koje dosad nisu postojale: npr. oporuke napravljene uz pomoć pametnih telefona, kamera ili računala. Sve ovakve oporuke izrazito su neformalne, no, istodobno, odražavaju pravu volju osoba koje su ih napravile. U većini država u svijetu takve “oporuke” nemaju nikakvog učinka, no, autorica obrađuje i niz slučajeva koji su se dogodili u pojedinim pravnim sustavima, u kojima su takve "oporuke" bile proglašene valjanima.

Izv. prof. dr. sc. Dubravka Klasiček

Doc. dr. sc. Davorin Pichler 